\title{
(S)CARS
}

\section{Exploring America's Automotive Self}

$T$ he American Midwest. I am soaking wet, looking for a Walmart, and desperate. My footwear is ruined; the sole of my left shoe has come off in the rain, and now flaps pathetically with every step I take. I muster my courage and walk up to a friendly-looking passer-by, and, not daring (but very much tempted) to sneak under his umbrella, I ask where the nearest store where I could buy a pair of shoes might be.

"Ah, take the first left, and then straight. Five minutes."

"Thank you."

I do take the first left, and then walk straight. Five minutes. Evident absence of Walmart. Ten minutes. A Walmart billboard. Twenty five... Puddles larger than the Atlantic... still no Walmart. Why would the "nice man" lie through his teeth? And suddenly... there it is. Walmart. Of course.

It was me, stupid Paweł, an Eastern European rookie in America. Five minutes, indeed.

By car.

Beyond doubt, Grinnell College is one of the most prestigious liberal arts colleges in the United States, and so when the brilliant neurodiversity scholar, an excellent Melvillean, and acclaimed poet Ralph Savarese offered me a guest professorship there, I was as overjoyed as I was terrified. Above all, however, I was excited at the prospect of a long journey. The first four legs of it turned
Pawet Jedrzejko RIAS Managing Editor IASA President University of Silesia in Katowice

Poland

(iD) 
out to be tiresome and boring, but easy: Katowice-Warsaw (a train ride). Warsaw-Heathrow (a flight). Heathrow-O'Hare (another flight). O'Hare-Des Moines (one more flight). The last 60 miles, albeit (theoretically) promising novelty of experience and therefore a far greater fun, could have proven far more difficult than the previous 6,000.

It could have been so, because Grinnell College-its excellence, welldeserved reputation, and friendliness notwithstanding-like many respectable institutions of higher education in the United States, is located in the middle of a very picturesque nowhere, the only artery connecting it to the world being the Interstate 80 , which boldly crosses the fascinating endlessness of the Great Plains, greening with acres and acres of an awe-inspiring gamut of all the varieties of corn humankind has ever cultivated. Once in Des Moines, one quickly realizes that the AmTrak or Greyhound connections to Grinnell have long been discontinued due to the paucity of commuters ready to use public transportation. On arrival, one's options are limited to three: rent a car (and hope that your foreign credit card works), bum a ride (and hope that people will not be scared of your accent), or walk. Or, if you are really lucky, waiting in the lobby will be professor Savarese, who, feelingly, will have come to fetch you.

Of course, by car.

CarCulture(s) Machines, Roads Mythologies

While in the Great Plains a car is a basic necessity, in other locations the very thought of owning one is strange. When you sing sea shanties, it is likely that the sailing clubs inviting you to give concerts in New York and its vicinities will offer you a lodging on board of a comfortable boat in the Kings Marina in Jamaica Bay. Accommodated at the far end of Brooklyn, however, a less experienced visitor to the City, a 'gringo,' whose concept of space is European, might be tempted to make his or her life easier. I have experimentally proven that one of the least intelligent ideas you may come up with attempting to cut the commuting time from the end of Flatbush Avenue to Western Manhattan is renting a car. If you are lucky (i.e. if it does not rain, if there is no roadwork, if there are no detours, accidents, or parades, if tunnels or bridges are all open), the 23 miles will take about 50 minutes to cover. But once you have arrived at your destination, a plethora of ominous signs, 
representing the whole of the legacy of Western and Eastern thought alike, will make you realize the gravity of your error.

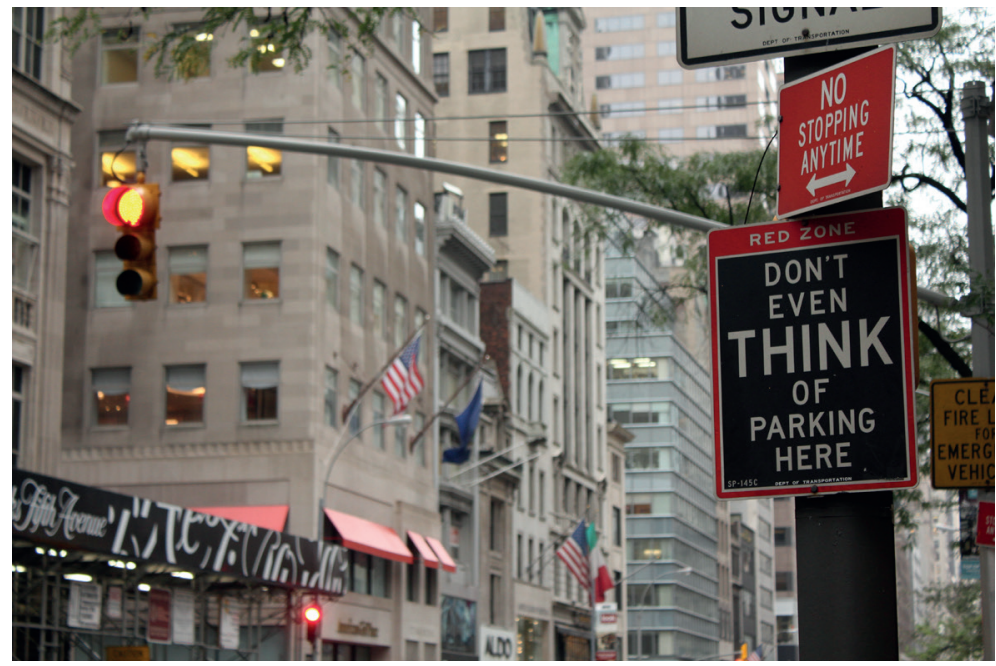

Fig. 1: Sunny Ripert, “Don't even think of parking here” (2010). Source: https://www. flickr.com/photos/sunfox/5085477774 (CC BY-SA 2.0).

Wherever you drive, you will face the somewhat deconstructivist imperative "Don't even THINK of parking here"2-staring at you from omnipresent signs and billboards. Not unlike Sinners in the Hands of an Angry God, unauthorized vehicles are doomed to being "towed, crushed, and melted," "worked over with sledgehammer, flipped over by an angry mob, set on fire, and spray painted with rude slogans immediately after being used as a getaway car in an incredibly daring daylight robbery." You cannot but profoundly reflect upon your parking choices in terms of Werner Heisenberg's quantum mechanics when you learn that "the last car to trespass is still missing" and you cannot avoid thinking of the cruelty of obeseism and your own dietary habits when you encounter signs that read: "Don't even think of parking your big rear here," or "Parking for disabled persons, not for fat people. You should have a parking

1. All of the "No Parking" signs, whose contents are quoted in this article, actually exist. A simple Google search for images tagged as "no parking" AND "sign" AND "New York City" will bring up all of the material referenced in this section and much more.

2. - which is largely reminiscent of the words of the wise man from an Eastern parable, who offers the ruler of Baghdad a magic carpet which will only fly if the sultan refrains from thinking of a cow.

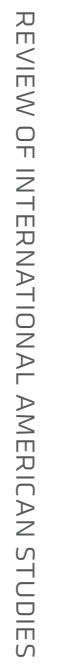

Pawet Jędrzejko RIAS Managing Editor IASA President University of Silesia in Katowice Poland 
spot 3 miles away and be required to do jumping jacks all the way to the store (\$1000 fine)." Ageism will rear its ugly head as well when you discover that the spot you find particularly attractive is "for nice old ladies only (Mean old lady parking in rear by dumpster)." Posthumanist reflection inevitably awakens when you learn that you are not allowed to park "[...] unless you are a turkey," or that parking space is reserved for: alpaca lovers only ("violators will be spit on"), beekeepers only ("violators will be stung"), butterfly lovers only ("all others must fly away"), Bigfoot only ("violators will be sasquatched"), and many, many other semi-human, non-human, or animal-relatied subjectivities.

Alternatively, local traffic hermeneuts of the elder generation, well read in Heidegger and Sartre, may ask you to "visualize yourself being towed," reminding you, at the same time, of the doctrine that "ignorance of law is no excuse." Expressed in a perhaps less elegant, but more efficient fashion as "stupidity is not a handicap," this concept presupposes a somewhat Darwinian idea of the survival of those, who develop intelligence in order to adapt best. Furthermore, your inclination towards a reflection upon the concepts of conjunction and alternative, especially in the context of the set theory, will skyrocket when you learn, for instance, that "People who park in front of [the] door are either blind, illiterate, ignorant f--ls; or residents of [the] house," or when you start wondering whether you really belong in the "Hippie parking only" zone, knowing that it is not you, but "all others" who "will be stoned." In this largely

CarCulture(s) Machines, Roads Mythologies biblical context, soteriology (or Monty Python) comes to mind: you must beware that when you park illegally in a zone marked "Church parking only," violators "will be baptized," but if you are already dogmatically religious, the sign "Thou shalt not park here" will drive the point home anyway. If further argumentation is needed then signs proclaiming that "violators will be shot, survivors will be shot again," which message clearly reinforces the Calvinist idea of the inevitability of the doom for the unregenerate, may prove very convincing. If all that fails, expressionist poetic miniatures, such as "If you take my place I will break your face," might do the job.

Admittedly, not all of the New YorkCity no-parking signs threaten you with fire and brimstone. You may also receive some friendly, educational advise. You may, for instance, learn that "Monkeys 
poop on windshields." Such valuable zoological knowledge is likely to cue your Cartesian reason to awaken, motivating you to seek a different spot. Yet, even more efficient are the signs positively laden with psychiatrically sound argumentation ("You gotta be nuts to be parking here"), or those transferring magic realism to social practice: "Customer parking only: all others will be toad."

Of course, occassionally, you are welcome to park. But when philosophy of friendship is exercised in parking areas, you are usually advised to consider the existential consequences of the choices you face. Knowing that although "It is not illegal to park here, [...] you should be aware that [trucks] trying to get delivery access through the adjacent gates could seriously modify your car," or that, choosing a spot, you should "beware of a vociferous lady with a very short fuse," you realize that Newton's Third Law of Motion works in the spaces of aesthetics and social relations as well as in physics.

More often than not, however, the shamanist logic of the world threatens to be incontrovertible. Should you wish to test their patience, "the wrath of the Ancients will fall upon your head, your shoelaces will not stay tied, rabid squirrels will invade your home, food in your refrigerator will mysteriously spoil, your vehicle will start making that expensive knocking sound again and no-one will talk to you at parties. (You will also seriously piss off the $b^{*}$ tch who paid good money for the garage, and nobody wants that)."

After an hour of intensive learning, you arrive at the conclusion that your only choice is a fee-paying parking lot (about $\$ 75$ per day) far away from your destination, and that irrespective of how far from the heart of Manhattan you are accommodated, you would rather shoot yourself in the knee than forgo the now magnetic allure of the public bus and subway in the future. Especially when all of your New York friends, whom you owe an honest explanation as to why you arrived late to band practice, roll on the floor laughing when you tell them that you came...

...by car.

My nerdobiographical humor aside, learning from (s)cars allowed me-and probably countless others-to not only acquire basic survival skills in the context of the norms of life in America, but also to appreciate the complexity of the American car culture, 
which has proven instrumental in the shaping of the course of the US history of the last 150 years. Cars have built Detroit. Cars have been mobile homes to innumerable Joad families during the Great Depression. Cars have driven the Cheney-Rumsfeld oil wars. Even the typology of literary currents in America has proven to depend on a car-related incident. After all, literary historians would not have heard of the Lost Ceneration if not for the fact that Certrude Stein was a driver.

Ernest Hemingway thus recalls the context, in which his friend and mentor allowed herself to reduce the war-time trauma of countless individuals to a single, offensive, label:

It was when we had come back from Canada and were living in the rue Notre-Dame-des-Champs and Miss Stein and I were still good friends that Miss Stein made the remark about the lost generation. She had some ignition trouble with the old Model T Ford she then drove and the young man who worked in the garage and had served in the last year of the war had not been adept, or perhaps had not broken the priority of other vehicles, in repairing Miss Stein's Ford. Anyway he had not been sérieux and had been corrected severely by the patron of the garage after Miss Stein's protest. The patron had said to him, "You are all a génération perdue."

"That's what you are. That's what you all are," Miss Stein said. "All of you young people who served in the war. You are a lost generation."

"Really?" I said.

"You are," she insisted. "You have no respect for anything. You drink yourselves to death...."

"Was the young mechanic drunk?" I asked.

CarCulture(s) Machines, Roads Mythologies

"Of course not."

"Have you ever seen me drunk?"

"No. But your friends are drunk."

"I've been drunk," I said. "But I don't come here drunk."

"Of course not. I didn't say that."

"The boy's patron was probably drunk by eleven o'clock in the morning," I said. "That's why he makes such lovely phrases."

"Don't argue with me, Hemingway," Miss Stein said. "It does no good at all. You're all a lost generation, exactly as the garage keeper said." (Hemingway 2010:45-46).

"The hell with her lost-generation talk and all the dirty, easy labels"the writer bursts out years later, reminiscing about the impact that the clash with Gertrude Stein had on him (Hemingway 2010:46). Unlike his mentor, who cuts him short when he attempts to draw 
her attention to the insensitivity of her comment, Hemingway, a former ambulance driver himself, empathizes with the hapless mechanic, whose war-time wounds, perhaps much like his own, would not heal. The paths of their common experience, masqueraded in the language of technical description, intersect in the cockpit of an ambulance:

Later when I wrote my first novel I tried to balance Miss Stein's quotation from the garage keeper with one from Ecclesiastes. But that night walking home I thought about the boy in the garage and if he had ever been hauled in one of those vehicles when they were converted to ambulances. I remembered how they used to burn out their brakes going down the mountain roads with a full load of wounded and braking in low and finally using the reverse, and how the last ones were driven over the mountainside empty, so they could be replaced by big Fiats with a good $\mathrm{H}$-shift and metal-to-metal brakes. I thought of Miss Stein and Sherwood Anderson and egotism and mental laziness versus discipline and I thought who is calling who a lost generation? (Hemingway 2010:46).

Although her original comment is off the mark, the formulation itself pinpoints the nature of the existential condition of Hemingway's generation very well: the Great War undoes the language, including the language of values, thereby eliminating guidelines that would organize people's navigation in the world before. The Lost Ceneration is perdue not because it is worthless, but because is has lost its bearings in a reality in which words like "honor," "love," "progress," "ethics," or "transcendence" lost their credibility in confrontation with the nature of the modern warfare. ${ }^{3}$ Furthermore, the generation of parents who, remembering the Great War and the Great Depression, were content to heal their existential scars with material goods in which post-World War Two America abounded, gave rise to the generation of Holden Caulfields, Neal Cassadys, and other rebels-(allegedly) without a cause. Unable to engage their parents in a meaningful communication, and at a loss for words that

3. I dedicate much more space to the philosophical fundaments of the Lost Generation in a chapter titled "Zagubione pokolenia: Auschwitz, Guernica i wyczerpany język. Wokół powieści Słońce też wschodzi Ernesta Hemingwaya" [Lost Generations: Auschwitz, Guernica, and Exhausted Language. On Ernest Hemingway's The Sun Also Rises] (Jędrzejko 2017). 
the prosperous Cold War America would understand, these 'rebels,' like James Dean and his iconic Jim Stark, would choose to live far too hard, drive far too fast, and often die far too young. It is some of these (s)cars that David Cronenberg brings back into light in his disconcerting 1996 film Crash, in which, in the face of the absurdity of life, he explores the psychoerotic allure of death.

By car.

If we agree that the car is a uniquely American symbol, we may choose to read America's turbulent history through the transformations of her automotive icons. Beginning with the Ford Model T, to Willys Jeep, to Chevy Bel Air, to Ford Fastback Mustang GT, to Chevy Corvette or, more recently, to the "safe" urban Hummer (one of the many military cars turned civilian) it is possible to trace the moments in history when fear yields to hubris, when hubris yields to humility, or when humility dissolves in the sheer pragmaticism of owning the wheels. One may learn America entering into an intimate relationship with her automotive self. One can explore America in four dimensions by car. And if we agree that modern American history has, by and large, been driven by, on, in, or in front of cars, we will also see how cars have become the vehicles of ethics, which could not be reduced to the simple fact that some carry provisions to those in need, others give individuals and groups a sense of self-esteem, and still others harbinger destruction. Ethics transform in the aftermath of major historical traumas. In America,

CarCulture(s) Machines, Roads Mythologies the remaining trace of each such trauma is a (s)car.

Pawet Jędrzejko

RIAS Managing Editor

IASA President 
WORKS CITED

Hemingway, Ernest. A Moveable Feast. Scribner, 2010.

Hilarious funny parking signs, https://www.google.com/search?q=hil arious+funny+parking+signs\&tbm=isch\&hl=en\&sa=X\&ved $=2$ ahUKEwjU24Xt49v0AhWDBncKHfKtDbcQrNwCKAB6BQgBEL YB\&biw=1903\&bih=880\#imgrc=835hE83pZzk5vM, accessed 08.11 .2021$.

Jędrzejko, Paweł. “Zagubione pokolenia: Auschwitz, Guernica i wyczerpany język. Wokół powieści Słońce też wschodzi Ernesta Hemingwaya," in: Ernest Hemingway. Edited by Ewa Barbara Łuczak. Wydawnictwa Uniwersytetu Warszawskiego 2017, pp. 57-73.

PawetJędrzejko RIAS Managing Editor IASA President University of Silesia in Katowice Poland 
